\title{
Migrant Rights in International Law: Exploring the Gendered Experiences of Migrant Women and Girls
}

Jenny Poon*

DOI: $10.21827 / 5 b f 3 e a 1966 a b 8$

\section{Keywords \\ MIGRANT WOMEN AND GIRLS; CEDAW; GENDER GUIDELINES; VULNERABILITY; SUSTAINABLE DEVELOPMENT GOALS}

\begin{abstract}
Migrants are people who choose to move from one place to another to seek a better life. However, when these people move across international borders as a result of fleeing from a 'well-founded fear of persecution' and not based on choice, they are forced migrants. This article examines the situations when women and girls move across international borders in order to flee from persecution or massive violations of human rights linked to gender violence. The article argues that women and girls experience vulnerabilities at all stages of the migration cycle not only because they are forced migrants fleeing from life-threatening situations, but also as a result of violations of their human rights based on gendered experience. An examination of the Convention on the Elimination of All Forms of Discrimination Against Women and the Immigration and Refugee Board of Canada's Chairperson's Guideline No 4 shows that, when these instruments are misapplied or not considered, the vulnerabilities of migrant women and girls may be exacerbated by such misapplication or non-consideration. This article ends by concluding that a focus should not be upon a woman or girl's vulnerability, but on her agency to be self-reliant and resilient towards her own destiny.
\end{abstract}

\section{Introduction}

Migrants are defined as those who 'choose to move not because of a direct threat of persecution or death, but mainly to improve their lives by finding work, or in some cases for education, family reunion, or other reasons'. ${ }^{1}$ According to the United Nations (UN), displacement is the 'forced movement of people from their locality or environment and occupational activities. It is a form of social change caused by a number of factors, the most

* Ph.D. Candidate; Faculty of Law, University of Western Ontario. The author wishes to thank Dr. Valerie Oosterveld for helpful and insightful comments in an earlier draft. The author would also like to thank the American Society of International Law for accrediting student observers, and the Faculty of Law, University of Western Ontario for the opportunity to attend the $61^{\text {st }}$ Session of the Commission on the Status of Women at the United Nations, New York, which inspired ideas for this article. All views and any errors are the author's own.

1 United Nations High Commissioner for Refugees (UNHCR), Edwards, A, UNHCR Viewpoint: 'Refugee' or 'migrant' - Which is right?, 11 July 2016, at <unhcr.org/news/latest/2016/7/55df0e556/unhcr-viewpointrefugee-migrant-right.html> (accessed on 18 November 2018). 


\section{Migrant Rights in International Law: Exploring the}

common being armed conflict'. ${ }^{2}$ For the purpose of this article, the focus will be upon migrants who are displaced, especially forced migrants or refugees.

More people are displaced around the world than ever before. In fact, according to an estimate by the UN High Commissioner for Refugees (UNHCR), 65.3 million people were forcibly displaced around the world in 2015 as a result of persecution, conflict, generalised violence or human rights violations. ${ }^{3}$ Of those displaced around the world in $2015,47 \%$ of them are women, while $51 \%$ are under the age of $18 .{ }^{4}$ The significance and relevance of ensuring international protection for migrant women and girls should therefore not be undermined. In fact, the UN Assistant Secretary-General has stated that 'displaced and migrant women and girls are commonly subject to multiple and intersecting forms of discrimination. On top of gender-based discrimination, they may be targeted on additional grounds such as race, disability or belonging to a minority group'. ${ }^{5}$ Now more than ever, States' compliance with international law affecting forced migrants should be closely monitored and scrutinised.

This article therefore aims to raise awareness of the situation of migrant women and girls and to encourage more stringent monitoring and scrutiny over how and whether the international human rights regime is in fact effective in encouraging migrant women and girls to achieve self-reliance and resilience. This article seeks to draw the attention towards better monitoring and scrutiny of the international treaty regime, as well as certain 'soft law' guidance instruments, in hopes that improvements can be made to assist migrant women and girls to resist being passive victims of their plight but be powerful actors in their own right.

To this end, this article will focus specifically on the situation of migrant women and girls and how their experiences are multifaceted due not only to the vulnerabilities they experience based on sex, but also the reinforcement of such vulnerabilities by international treaty law and 'soft law' guidance instruments, such as the Convention on the Elimination of All Forms of Discrimination Against Women (CEDAW) and the Immigration and Refugee Board of Canada Chairperson Guideline No. 4 (Gender Guideline), when these instruments are misapplied, disregarded or lack punitive measures. The vulnerabilities of migrant women and girls may be exacerbated in three ways. First, this article argues that the lack of punitive measures for, and the non-binding nature of, CEDAW Committee communications to States parties are problematic. Secondly, the inconsistent application and the non-consideration of 'soft law' guidance instruments such as the Gender Guideline create additional barriers for migrant women and girls. Third, the lack of coordination among States for implementing the Sustainable Development Goals adds to the difficulties faced by migrant women and girls. This article does not claim that the international law regime concerning the human rights of

2 United Nations Educational, Scientific and Cultural Organization (UNESCO), Displaced Person/Displacement, at <unesco.org/new/en/social-and-human-sciences/themes/international-migration/glossary/displacedperson-displacement> (accessed 18 November 2018).

3 UNHCR, REPORT: Global Trends Forced Displacement in 2015, 20 June 2016, at $<$ unhcr.org/576408cd7.pdf\%20[Global\%20Trends\%20Report> (accessed 18 November 2018), 2 (UNHCR Global Trends Report 2015).

4 Ibid.

5 UN Women, Puri, L, Op-ed: Empowering Women and Girl Migrants and Refugees, 15 September 2016, at <unwomen.org/en/news/stories/2016/9/op-ed-empowering-women-and-girl-migrants-and-refugees> (accessed 18 November 2018) (UN Women and Puri). 
migrant women and girls is not effective, but that the misapplication or misinterpretation of these norms may lead to the exacerbation of vulnerabilities of these individuals while perpetuating the cycle of harm suffered. This article suggests that one reason that may contribute towards the problems of misapplication and misinterpretation of norms is a broader issue inherent within the structure of international law, as set up by the top-down implementation approach of the Westphalian State-centric model. This article concludes by recommending that with the right tools, migrant women and girls can be agents of change themselves - empowered to achieve self-reliance and resilience in the midst of their strife.

\section{A. Context and Overview}

The UN 61 ${ }^{\text {st }}$ Session of the Commission on the Status of Women (CSW61) was held at the UN Headquarters in New York City on March 13-24, 2017. CSW61 brought together activists, students, academics, civil society, UN entities, and government representatives to examine ways to empower women and girls and to achieve gender equality. The meeting could not have been timelier due to the number of forcibly displaced persons currently around the world. In fact, according to a Global Trends Report by the UNHCR in 2015, 'wars and persecution have driven more people from their homes than at any time since UNHCR records began'. ${ }^{6}$ These statistics not only show the significance and relevance of international protection needed for these vulnerable migrants, but also highlight the urgent need for States to apply international law properly in their domestic order. The issue of migration is of particular interest. Migrant women and girls are a group of individuals who experience additional barriers as a result of the multifaceted vulnerabilities they face as migrants and women and girls, some of whom are forcibly displaced, as well as a 'well-founded fear of persecution'.

This article will argue that, contrary to mainstream academic commentaries, when international treaty law and 'soft law' guidance instruments are applied inconsistently, disregarded, or misapplied, this misapplication of the law may reinforce the vulnerabilities of migrant women and girls, instead of permitting States to equip them with the tools necessary to achieve self-reliance and resilience. Rather than a critique on the law as it is, this article suggests that the application or interpretation of the law, when incorrect or not considered, may undermine the original purpose of that law. This article will demonstrate how the vulnerabilities of migrant women and girls may be reinforced in the misapplication of international treaty law by using CEDAW as an example and by examining the term 'discrimination against women' as set out by CEDAW. Next, Canadian jurisprudence where the Gender Guideline should have been considered will be used as an example to illustrate how, contrary to the purpose of the Gender Guideline to encourage more gender-sensitive tribunal decisions, the opposite generally occurs due to the misapplication of the Gender Guideline or the failure to consider the Gender Guideline at all.

Due to the limited scope of this article, the focus will be upon CEDAW and the Gender Guideline instead of other gender guidelines issued by countries, such as the United Kingdom, or international organisations such as the UNHCR. The methodology employed by this article

6 UNHCR, Edwards, E, Global Forced Displacement Hits Record High, 20 June 2016, at <unhcr.org/afr/news/latest/2016/6/5763b65a4/global-forced-displacement-hits-record-high.html> (accessed 18 November 2018). 
will involve an examination of the travaux préparatoires, or preparatory works, of the primary international instrument protecting the rights of women, CEDAW, as well as the text of the 'soft law' guidance instrument which is the Gender Guideline. CEDAW was chosen as a starting point of analysis because it is the primary international instrument for the protection of women and girls from discrimination. ${ }^{7}$ The Gender Guideline is a focus also due to it being the pioneer gender guideline of its kind focused on gender-related persecution by a refugee status adjudicative body. ${ }^{8}$

\section{B. The Significance and Relevance of Migrant Women and Girls}

The significance of examining the topic of migrant women and girls could not be more relevant now than ever before. Many migrant women and girls face discrimination, violence, and exploitation at various stages of the migration cycle as a result of their uniquely gendered experiences. For instance, migrant women and girls are more susceptible to being trafficked for sexual exploitation and constitute $98 \%$ of victims being trafficked. ${ }^{9}$ Also, the UN Sustainable Development Goal Target 10.7 is aiming to 'facilitate orderly, safe, regular and responsible migration and mobility of people, including through the implementation of planned and well-managed migration policies'. ${ }^{10}$ This Sustainable Development Goal is of particular relevance because it seeks to reduce the multiple vulnerabilities faced by migrant women and girls.

According to the UNHCR Global Trends Report of 2015, the global demographic characteristics of refugees shows that, between the years 2003-2015, almost 50\% of refugees worldwide were made up of women. ${ }^{11}$ Migrant women not only experience vulnerabilities as migrants, but are often subjected to additional barriers in certain cultures, such as in Yemen, where the large majority of women displaced by conflict are also single females heading households. ${ }^{12}$

\section{Key Definitions}

The definition of 'migrant' used by this article is taken from the UNHCR Emergency Handbook, which details the distinction between a 'migrant' and a 'refugee'. ${ }^{13}$ According to

7 Article 1, United Nations, Convention on the Elimination of All Forms of Discrimination Against Women (1979) 1249 UNTS 13 (CEDAW).

8 Sadoway, G, "The Gender Factor in Refugee Determination and the Effect of 'Gender Guidelines" in Hajdukowski-Ahmed, M, Khanlou, N, and Moussa, H, eds, Not Born a Refugee Woman: Contesting Identities, Rethinking Practices (Berghahn Books 2009), 244.

9 Global Migration Group, Policies Empowering Migrant Women and Girls in the Context of 2030 Agenda for Sustainable Development: CSW Side Event, 24 March 2016, at <globalmigrationgroup.org/system/files/FINAL\%20GMG\%20STATEMENT\%2024\%20March\%20CSW _1.pdf> (accessed 18 November 2018).

11 UNHCR Global Trends Report supra nt 3, 53 (Table 5).

12 Ibid., 31.

13 UNHCR Emergency Handbook, Migrant Definition, at <emergency.unhcr.org/entry/44938/migrantdefinition> (accessed 18 November 2018). 
the UNHCR, a migrant is 'any person who moves, usually across an international border, to join family members already abroad, to search for a livelihood, to escape a natural disaster, or for a range of other purposes'. ${ }^{14}$ Distinguished from a 'migrant', a 'refugee' is someone who is experiencing a 'well-founded fear of persecution' due to his or her race, religion, nationality, membership in a particular social group or political opinion, outside of his or her country of origin, is unwilling or unable to avail him or herself to State protection, and is unable or unwilling to return. ${ }^{15}$ Another definition which is used in this analysis is 'sex discrimination'. 'Sex discrimination' or 'discrimination based on sex' is defined under Article 1 of CEDAW, as detailed below. For the purpose of this article, migrant women and girls will also include women asylum claimants and refugees, who are forced migrants.

For the purpose of this analysis, the distinction between 'sex' and 'gender' must also be ascertained. Pursuant to the UNHCR Handbook and Guidelines on Procedures and Criteria for Determining Refugee Status, 'gender' refers to 'the relationship between women and men based on socially or culturally constructed and defined identities, status, roles and responsibilities that are assigned to one sex or another' ${ }^{16}$ Further, 'gender' is 'not static or innate but acquires socially and culturally constructed meaning over time'. ${ }^{17}$ 'Sex', on the other hand, is defined as 'a biological determination [i.e. maleness and femaleness]'. ${ }^{18}$ Henceforth, this analysis examines migrant women and girls as including both female asylum claimants and refugees who experience discrimination based on sex (discrimination based on the femaleness of claimant or refugee) rather than gender (discrimination based on the socially-constructed norm or characteristic of the claimant or refugee). 'Gender violence' is assumed, for the purpose of this article, to be violence experienced as a result of one's gender or violence experienced as a result of discrimination based on sex. For this analysis, the focus will be upon gender violence that occurs to migrant women and girls at stages during their migration cycle.

\section{Migration and Gender}

Gender is not an independent, enumerated ground for a 'well-founded fear of persecution' as defined under Article $1 \mathrm{~A}$ of the Convention Relating to the Status of Refugees (Refugee Convention). ${ }^{19}$ In other words, women asylum claimants cannot claim gender as a ground for experiencing a 'well-founded fear of persecution'. Rather, gender-related persecution has been widely recognised as a form of persecution and not a ground upon which persecution may be based. ${ }^{20}$ As a developing area of the law, the Gender Guideline pioneered by the Immigration

14 Ibid.

15 Article 1A, United Nations, Convention Relating to the Status of Refugees (1951) 189 UNTS 137 (Refugee Convention).

16 UNHCR, Handbook and Guidelines on Procedures and Criteria for Determining Refugee Status, December 2011, at $<$ unhcr.org/publications/legal/3d58e13b4/handbook-procedures-criteria-determining-refugee-status-under1951-convention.html> (accessed 18 November 2018) 87.

17 Ibid.

18 Ibid.

19 Immigration and Refugee Board of Canada, Chairperson Guidelines 4: Women Refugee Claimants Fearing GenderRelated Persecution, 13 November 1996, at <irb-cisr.gc.ca/en/legal-policy/policies/Pages/GuideDir04.aspx> (Gender Guideline) (accessed 18 November 2018); See also, Article 1A, Refugee Convention.

20 Ibid. 
and Refugee Board of Canada aims to address the unique experience of women refugees requiring special care and attention and is the first of its kind to do so.$^{21}$ However, this article posits that the Gender Guideline, although well-intentioned, is often disregarded even where gender elements are present in the case possibly due to its non-binding nature, which may ultimately prevent its purpose from being achieved.

Before diving into a discussion of the critiques of the misapplication and nonconsideration of international and 'soft law' guidance instruments relevant to migrant women and girls, it is also important to highlight the positive aspects of migration. For instance, migration can provide opportunities for migrant women and girls who struggle with patriarchal notions of gender norms, such as traditional gender roles. For some migrant women and girls, migration is a method of venturing into the brave new world, leaving behind culturally-established gender roles. Some scholars have also argued that, unlike inequalities in the workplace, migration create opportunities for women, such as allowing them to gain greater personal autonomy, getting jobs and confronting obstacles which may sometimes be easier for women..$^{22}$ The out-migration of women also gives them an advantage over men because of the increase in opportunities for work and marriage as is the case in Kerala and South Vietnam. ${ }^{23}$ Further, migrant women, who leave their villages to marry elsewhere, have enhanced status, so that their families have increased bargaining power in marriage transactions, resulting in greater preference for villagers to have girls rather than boys. ${ }^{24}$

Despite the positive sides of migration, there are, unfortunately, also negative aspects. For instance, although migration may improve women's lives by giving them opportunities outside of traditional gender roles, the women may have unrealistic expectations regarding the decision to migrate, lack the know-how and ability to cover expenses relating to migration, or are discriminated against, exploited or abused as migrants. ${ }^{25}$ This article therefore argues that migrant women and girls face additional barriers as both migrants and as women and girls in accessing international protection. It is often the result of these barriers and lack of access to protection that the international law regime and migrant rights under international law should be closely monitored and scrutinised to reduce vulnerabilities for these individuals.

\section{International Law Concerning Migrant Women and Girls}

21 Since its inception in 1993, the Gender Guideline has served as a model for other countries considering similar initiatives, including the United States and Australia; See also, Ramirez, J, "The Canadian Guidelines on Women Refugee Claimants Fearing Gender-Related Persecution", 14(7) Refuge: Canada's Journal on Refugees (1994) 3, at <refuge.journals.yorku.ca/index.php/refuge/article/view/21841> (accessed 18 November 2018).

22 Morokvašić, M, "Gendering Migration" 3 Institut za migracije i narodnosti (2014) 355-378, 368.

23 Ibid.

24 Ibid.

25 Kawar, M "Gender and Migration: Why are Women more Vulnerable?" in Reysoo, F and Verschuur, C, Femmes en Mouvement, (Graduate Institute Publications 2016) 73-75, at <graduateinstitute.ch/files/live/sites/iheid/files/sites/genre/shared/Genre_docs/2865_Actes2004/10m.kawar.pdf $>$ (accessed 18 November 2018). 
A central piece of the analysis in this article is focused upon the relationship between the misapplication of instruments of the international law regime and the vulnerabilities of migrant women and girls. The term 'international law regime' refers to the body of international treaty law, international custom, general principles of international law, as well as the scholarly outputs of highly-qualified publicists and judicial decisions of courts and tribunals. ${ }^{26}$ As reiterated earlier, the focus will be upon two particular instruments, the former being CEDAW, as an international treaty, and the latter being the Gender Guideline, as a 'soft law' instrument.

The section below will examine the international law regime that concerns migrant women and girls. First, international treaty law will be examined, followed by the 'soft law' guidance instruments applicable.

\section{A. The Legal Framework Relevant to Migrant Women and Girls}

\section{International Treaty Law}

The most prominent international instrument protecting women and girls from discrimination is CEDAW. There are more than 185 ratifications to CEDAW, and together with its optional protocol, both instruments are regarded as the 'cornerstone' of all UN Women programmes, including for the CSW61. ${ }^{27}$ The aim of UN Women is to work towards the elimination of discrimination against women and girls, to empower women, and to achieve gender equality between women and men. ${ }^{28} \mathrm{CEDAW}$ is therefore used as an example to illustrate how the lack of punitive measures and the non-binding nature of CEDAW Committee communications may reinforce the vulnerabilities of migrant women and girls instead of focusing on equipping these individuals with the right tools to achieve self-reliance and resilience.

Pursuant to the Vienna Convention on the Law of Treaties, which governs treaty interpretation, Article 31(1) provides that a treaty shall be interpreted in good faith, in accordance with the ordinary meaning given it based on the context and the object and purpose. ${ }^{29}$ Pursuant to Article 32, the travaux préparatoires of a treaty may be used as supplementary means of interpretation only where the ordinary meaning of a provision of the treaty will leave the meaning ambiguous or otherwise bring the meaning into absurdity. ${ }^{30}$ Therefore, the analysis of CEDAW should begin with an examination of its object and purpose, found in its preamble, which provides that:

26 Article 38, United Nations, Statute of the International Court of Justice, 18 April 1946, at $<$ refworld.org/docid/3deb4b9c0.html> (accessed 18 November 2018).

27 UN Women, Guiding Documents, at <unwomen.org/en/about-us/guiding-documents> (accessed 18 November 2018); United Nations General Assembly, Resolution Adopted by the General Assembly: Optional Protocol to the Convention on the Elimination of All Forms of Discrimination Against Women, 15 October 1999, A/RES/54/4, at < undocs.org/en/A/RES/54/4> (accessed 18 November 2018).

28 UN Women, About UN Women, at<unwomen.org/en/about-us/about-un-women> (accessed 18 November 2018).

29 Article 31(1), United Nations, Vienna Convention on the Law of Treaties (1969) 331 UNTS 1155 (VCLT).

30 Article 32, VCLT. 


\section{Migrant Rights in International Law: Exploring the}

[D]iscrimination against women violates the principles of equality of rights and respect for human dignity, [and] is an obstacle to the participation of women, on equal terms with men, in the political, social, economic and cultural life of their countries. ${ }^{31}$

As shown in the preamble, the object and purpose of CEDAW is to ensure respect for human dignity and to encourage the full participation of women on equal terms with men in the political, social, economic and cultural spheres of their countries. According to the object and purpose of CEDAW, therefore, and in order to enhance international protection for migrant women and girls and to address their vulnerabilities, it is important to recognise the selfreliance and resiliency of these individuals - the end goal of which is to enable and empower them to fully participate in their communities in various capacities, including participation at all levels of decision-making in the migration process.

CEDAW addresses discrimination against women by first ascertaining the meaning of the term 'discrimination against women', which is found under Article 1. Article 1 of CEDAW will be the main focus for the purpose of this article. Article 1 of CEDAW states that:

For the purpose of the present Convention, the term 'discrimination against women' shall mean any distinction, exclusion or restriction made on the basis of sex which has the effect or purpose of impairing or nullifying the recognition, enjoyment, or exercise by women, irrespective of their marital status, on a basis of equality of men and women, of human rights and fundamental freedoms in the political, economic, social, cultural, civil or any other field (emphasis added). ${ }^{32}$

In contrast to Article 1, which lays down what constitutes 'discrimination against women', Article 2 specifies how States parties must address their legal obligations under CEDAW in order to respect, protect and fulfill women's rights to non-discrimination and to enjoy equality.$^{33}$ Article 2 is too long to reproduce in this article, but the provision obliges States parties to protect women against discrimination by private parties and to take positive steps to eliminate or reduce all practices which prejudice and perpetuate inferiority of or superiority of either of the sexes and of stereotyped roles for men and women. ${ }^{34} \mathrm{It}$ is argued, therefore, stronger compliance with CEDAW provisions by private parties such as individual rights holders (who, it is argued, have a right to be protected from discrimination and also a corresponding duty to safeguard those rights) entails:

1. The incorporation of punitive measures to deter violation of those provisions; and

31 Preamble, CEDAW.

32 Article 1, CEDAW.

33 Para 9, CEDAW Committee, General Recommendation No 28 on the Core Obligations of States Parties under Article 2 of the Convention on the Elimination of All Forms of Discrimination against Women, 19 October 2010, at <www2.ohchr.org/english/bodies/cedaw/docs/CEDAW-C-2010-47-GC2.pdf> (accessed 18 November 2018) (General Recommendation 28).

34 Ibid. 
2. The strengthening of the binding nature of CEDAW Committee communications on States parties.

\section{2. 'Soft Law' Guidance Instruments}

The 'soft law' guidance instruments which this article will examine include both the Gender Guideline and UN Sustainable Development Goal No 10. The main provision which concerns this analysis is found under section AI of the Gender Guideline, which states that women refugees may be placed into four broad categories, one of which is 'women who fear persecution resulting from certain circumstances of severe discrimination on grounds of gender' ${ }^{35}$ In order to be recognised as refugees, women asylum claimants must demonstrate that the State is unwilling or unable to protect them. ${ }^{36}$ Sustainable Development Goal No 10 aims to reduce inequality within and among countries. ${ }^{37}$ Target 10.7 of the Sustainable Development Goal No 10 aims to 'facilitate orderly, safe, regular and responsible migration and mobility of people, including through the implementation of planned and well-managed migration policies'. ${ }^{38}$

Other 'soft law' guidance instruments concerning the treatment or experience of migrant women and girls, which not be the focus of this analysis, include: the UNHCR Executive Committee Conclusions on women and girls at risk and United Nations General Assembly Resolutions on violence against migrant workers. ${ }^{39}$

\section{B. The International Law Regime: Potentially Reinforcing the Vulnerabilities of Migrant Women and Girls?}

As reiterated above, the aim of CEDAW is to respect, protect and fulfil women's rights to non-discrimination and to enjoy equality. ${ }^{40}$ However, CEDAW provisions, as with other international human rights treaties, do not have enforcement mechanisms. While it is true that the CEDAW Committee does have a supervisory and monitoring role, it is insufficient because its communications are non-binding in nature. In other words, when specific provisions are violated by States parties, little can be done to bring justice to the victims of human rights violations, especially when there is a general lack of punitive measures against the States parties committing these violations other than 'naming and shaming'. ${ }^{41}$ Although

35 Section A.I.3, Gender Guideline.

36 Ibid.

37 United Nations Division for Sustainable Development Goals, Sustainable Development Goal 10, at $<$ sustainabledevelopment.un.org/sdg10> (accessed 18 November 2018) (SDGs).

38 Ibid.

39 See, UNHCR Executive Committee of the High Commissioner's Programme, Conclusion on Women and Girls at Risk No. 105 (LVII) - 2006, 6 October 2006, at <unhcr.org/excom/exconc/45339d922/conclusion-womengirls-risk.html> (accessed 18 November 2018); United Nations Inter-Agency Network on Women and Gender Equality, Women Migrant Workers, at <un.org/womenwatch/ianwge/resolutions/ ga_res_by_topic.htm\#14> (accessed 18 November 2018).

40 General Recommendation 28.

41 Interestingly, a statistical analysis conducted by Emilie M Hafner-Burton has shown that, although limited, human rights naming and shaming has certain positive effects on governments that are subjected to global publicity efforts, including a reduction in some violations of political rights afterward in Hafner-Burton, EM, "Sticks and Stones: Naming and Shaming the Human Rights Enforcement Problem" 62(4) International 


\section{Migrant Rights in International Law: Exploring the}

\section{Gendered Experiences of Migrant Women and Girls 311}

the problem of enforcement is prevalent among the international human rights regime, this lack of enforcement powers and thus punitive measures against States parties is especially detrimental for migrant women and girls. The following section discusses how the lack of punitive measures, the non-binding nature of CEDAW communications, the misapplication or non-consideration of the Gender Guideline, and the lack of coordination for implementing the Sustainable Development Goals as structural deficiencies of the international law regime may potentially contribute to the vulnerabilities of migrant women and girls.

\section{Lack of Punitive Measures and Non-Binding Communications of the Committee}

While mainstream scholarly literature may argue that the CEDAW framework and the international human rights law regime generally contribute to the safeguarding of individual rights for migrant women and girls, it is argued that the lack of punitive measures for CEDAW and the misapplication or non-consideration of the Gender Guideline may potentially reinforce the vulnerabilities of these individuals.

When CEDAW violators generally 'go free' without effective punitive measures, the vulnerabilities of migrant women and girls may be exacerbated. One example concerns the lack of punitive measures for violators of CEDAW provisions. For instance, in Jallow $v$. Bulgaria, the CEDAW Committee held that State authorities violated Articles 2(b), 2(c), 2(d), 2(e), and 2(f) of CEDAW as a result of failing to protect the applicant from domestic violence and failing to consider the allegation of violence when denying the applicant custody of her daughter. ${ }^{42}$ The applicant is a Gambian citizen submitting the communication for herself and on behalf of her daughter M.A.P., a Gambian and Bulgarian national. ${ }^{43}$ The applicant alleges that she was forced to take part in pornographic films and photographs by her husband in Bulgaria and was subjected to psychological and physical violence, including sexual abuse. ${ }^{44}$ The applicant claimed that Bulgaria, as a State party to CEDAW, violated Articles 1, 2, 3, 5 and 16 of CEDAW as a result of the discriminatory treatment that she and her daughter, as women, received from its authorities, and Bulgaria's failure to protect them from domestic gender-based violence and to sanction the perpetrator. ${ }^{45}$ Despite the fact that Bulgaria was found to be in violation of Articles 2, 5, and 16 of CEDAW, and the applicant and her daughter have suffered serious moral and pecuniary damage and prejudice, the remedy applied by the CEDAW Committee was compensation to the victims of the human rights

Organization (2008) 689-716, at <cambridge.org/core/services/aop-cambridge-core/content/view/ 39C386310B323A85E58F4E687CA5F7D9/S0020818308080247a.pdf/sticks_and_stones_naming_and_sha ming_the_human_rights_enforcement_problem.pdf> (accessed 18 November 2018).

42

CEDAW Committee, Isatou Jallow v Bulgaria, Communication No 32/2011, 28 August 2012, CEDAW/C/52/D/32/2011, at <www2.ohchr.org/english/law/docs/CEDAW-C-52-D-32-2011_en.pdf> (accessed 18 November 2018) (Jallow); See also, Open Society Justice Initiative, Case Digests: UN Committee on the Elimination of All Forms of Discrimination against Women, June 2013, 4, at <opensocietyfoundations.org/sites/default/files/case-digests-cedaw-june-2012-20130619.pdf> (accessed 18 November 2018) (Case Digest).

43 Jallow, paras 1 and 2.

44 Jallow, para 2.2.

45 Jallow, para 3.1. 
violation 'commensurate with the gravity of the violations of their rights'. ${ }^{46}$ This case demonstrates that, while violations of CEDAW provisions take place and such violations are denounced by the CEDAW Committee (known in human rights as 'naming and shaming'), little is in fact done to punish the human rights violator or bring justice to the victims of violation other than requiring the violator to compensate the victim.

Although authoritative, the non-legally binding nature of the communications issued by the CEDAW Committee is compounded with the problem of applying the CEDAW communications by States parties. ${ }^{47}$ The non-legally binding nature of CEDAW Committee's decisions create barriers for victims of human rights violations, such as migrant women and girls, to achieve justice. For example, States parties that are found to have violated specific provisions of CEDAW may reduce their violations as a result of being named and shamed; however, in reality, since CEDAW Committee decisions are non-legally binding, States parties are not under a legal obligation to comply. While the CEDAW Committee has mechanisms to monitor States parties' compliance with its decisions (termed 'follow-up procedures') and States parties to CEDAW have accepted to respect the Committee's findings, States parties are nonetheless free to deviate from the recommendations without significant penalty. ${ }^{48}$ Compared to individual migrant women and girls whose rights have been violated, the scale is tipped in favour of the resourceful States party found to have violated those rights.

\section{Inconsistent Application or Non-Consideration of the Gender Guideline}

Another issue that must be addressed is the inconsistent application or the non-consideration of the Gender Guideline by Canadian tribunals. For the purpose of this analysis, the focus will be upon the Refugee Protection Division of the Immigration and Refugee Board of Canada's adjudication of refugee status claims affecting women and girls in the context of forced migration. Given the limited scope of this article, the analysis will focus upon a specific and limited number of cases, rather than a holistic overview of cases over a broad spectrum.

The case of $M D E$ demonstrates how the Gender Guideline was not taken into consideration in the refugee tribunal's decision-making on granting refugee status to a claimant, even where the claimant alleges that there are gender-related elements to her claim. ${ }^{49}$ In this case, the claimant is from India and, following the death of her husband, her tenant stopped paying rent and started to act hostilely towards her. ${ }^{50}$ The claimant then fled to Canada due to the police's failure to respond to the threats. ${ }^{51}$ However, the gendered-element of her claim, which is the fact that she was targeted as a result of being an older, widowed woman in India, was not considered by the Immigration and Refugee Board before rejecting her asylum application, nor was it considered by the Federal Court on appeal. ${ }^{52}$ In the case of

\footnotetext{
46 Jallow, paras 8.7 and 8.8(1); See also, Case Digest, supra nt 42, 17.

47 United Nations Office of the High Commissioner for Human Rights, Human Rights Treaty Bodies - Individual Communications, at <ohchr.org/EN/HRBodies/TBPetitions/Pages/IndividualCommunications.aspx> (accessed 18 November 2018).

48 Ibid.

49 Federal Court (Citizenship and Immigration), Devi v Canada [2008] FC 1110.

50 Federal Court (Citizenship and Immigration), Devi v Canada [2008] FC 1110, para 2.

51 Federal Court (Citizenship and Immigration), Devi v Canada [2008] FC 1110, para 2.

52 Federal Court (Citizenship and Immigration), Devi v Canada [2008] FC 1110, para 10.
} 
$J W N$ the claimant was granted refugee status although the Gender Guideline was not considered by the Immigration and Refugee Board or the Federal Court. ${ }^{53}$ The claimant applied for refugee status on the basis of a 'well-founded fear of persecution' from her parents and prospective husband that she would be subjected to forced marriage and female genital mutilation. ${ }^{54}$ These two cases show that despite the relevance and significance of the Gender Guideline and the presence of gender elements in the claim, in certain cases, the Immigration and Refugee Board of Canada or the Federal Court may not take the Gender Guideline into consideration in their decision-making. Where the Gender Guideline is not considered, it becomes problematic because it may contribute towards inconsistency in decision-making, and may undermine the protection regime enhanced by the Gender Guideline for migrant women and girls, especially those fleeing from a 'well-founded fear of persecution'. Another example is seen in the case of MSM, where the Immigration and Refugee Board of Canada rejected the applicant's claim for refugee status without considering the Gender Guideline despite the claimant's allegation of sexual assault in the context of employment. ${ }^{55}$ At the Federal Court level, it was held that not considering the Gender Guideline was problematic, but the court did not rule on whether the Immigration and Refugee Board should have considered the Gender Guideline. ${ }^{56}$

Yet another problem is inherent in the non-binding nature of the Gender Guideline. Although Immigration and Refugee Board of Canada adjudicators must apply the guidelines unless compelling reasons require departing from them, the Gender Guideline itself is nonbinding and therefore need not be followed in every case. ${ }^{57}$ This fact makes it possible for adjudicators to not follow the Gender Guideline which may become regular practice. Instead, the Refugee Protection Division of the Immigration and Refugee Board of Canada's determination on whether to consider and apply the Gender Guideline should be performed uniformly over a wide spectrum of cases, rather than solely on a case-by-case basis. Similar to the lack of punitive measures for CEDAW violations, the non-binding nature of the Gender Guideline, it is argued, contributes to instances where the Gender Guideline may not be considered. The non-consideration of the Gender Guideline where gender elements are often present in the claim may result in its inconsistent application, potentially increasing the chances of impunity for human rights violators including contributing towards the vulnerabilities of migrant women and girls.

While some may argue that compensation is a type of 'punishment' for the human rights violator, it is suggested instead that compensation cannot possibly repair the damage done to migrant women and girls who have suffered from the hands of these violators. In some cases, the harm suffered from human rights violators may be so severe, that the migrant women and girls affected are scarred for life. For example, the case of a Roma claimant who

53 Federal Court (Citizenship and Immigration), JWNv Canada [2004] FC 432.

54 Federal Court (Citizenship and Immigration), JWN v Canada [2004] FC 432, para 3.

55 Federal Court (Citizenship and Immigration), MSMv Canada [2005] FC 147, para 3.

56 Federal Court (Citizenship and Immigration), MSMv Canada [2005] FC 147, para 19.

57 LaViolette, N, "Gender-Related Refugee Claims: Expanding the Scope of the Canadian Guidelines" 19 International Journal of Refugee Law (2007) 169, 169-214. 
was raped by four men, one of whom was the son of a high-ranking police officer. ${ }^{58}$ As a result of a violation of her rights, the Roma claimant had to live with repercussions of being a rape survivor for the rest of her life. In this case, any amount of compensation would not have repaired the damage suffered. In another case, a claimant from India was suffering domestic abuse from her husband and was subjected to regular beatings from him. ${ }^{59}$ The harm suffered as a result of recurrent domestic abuse at the hands of her husband may result in PostTraumatic Stress Disorder or other severe aftereffects which may be detrimental to the claimant for the rest of her life. In this case, as with other cases mentioned, compensation cannot possibly repair the damage done.

Some scholars may also argue that the lack of enforcement mechanisms in international law is a general problem indicative of the way international law is structured; rather than a specific problem similar to CEDAW or the Gender Guideline, it is argued that the broader issue of the lack of punitive measures for human rights violators and the inconsistent application or non-consideration of 'soft law' guidance instruments, such as the Gender Guideline, can contribute to exacerbating the situation for migrant women and girls. For instance, where human rights violators are not punished for their violations, it may incentivise additional violations of those human rights. ${ }^{60}$ Further, migrant women and girls are, arguably, more vulnerable than women and girls who are not migrants, as a result of the multifaceted layers of vulnerabilities migrant women and girls experience at all stages of the migration cycle. For example, as asserted by the UN Assistant Secretary-General, migrant women and girls 'face a series of challenges, which include psycho-social stress and trauma, health complications, [and] physical harm and risk of exploitation' ${ }^{61}$

In addition, inconsistent application or the non-consideration of 'soft law' guidance instruments, which are by nature persuasive though non-binding, may nullify or undermine the effects of having these instruments in the first place. In other words, these 'soft law' guidance instruments may be undermined to the extent that, in the end, it may result in discretionary decision-making. Moreover, the procedural safeguards put into place by these 'soft law' guidance instruments, such as the Gender Guideline, are important guarantees that should not be ignored by adjudicators during decision-making. The current prevailing trend seems to suggest that on the one hand, the Gender Guideline is being considered and followed in some cases where gender elements are present, while on the other hand, it is neither followed nor considered regardless of the presence of gender elements in the application. This inconsistency in asylum decision-making, it is argued, may potentially contribute towards the vulnerabilities of migrant women and girls in that the misapplication or non-consideration of the Gender Guideline may ultimately influence whether migrant women and girls are granted refugee status.

58 Immigration and Refugee Board of Canada, Refugee Protection Division, Case No CRDD T98-04880, 20 October 1999.

59 Immigration and Refugee Board of Canada, Refugee Protection Division, Case No CRDD MA 1-02285 et al., 8 March 2002.

60 CEDAW Committee, General Recommendation No 19 (1 th Session, 1992) Violence Against Women, at <un.org/womenwatch/daw/cedaw/recommendations/recomm.htm\#recom19> (accessed 18 November 2018) para 24(g): For instance, it has been recommended by the CEDAW Committee that 'specific preventive and punitive measure are necessary to overcome trafficking and sexual exploitation'.

61 UN Women and Puri, supra nt 5. 


\section{Lack of Coordination for Implementing the Sustainable Development Goals}

The lack of coordination among States in the implementation of the Sustainable Development Goals is also an area of concern which may contribute towards the vulnerabilities of migrant women and girls. For instance, it has been suggested by Bond, a British organisation that focuses on international development through research and training, that States may prioritise some Sustainable Development Goals over others. ${ }^{62}$ For instance, since migration is a highlypoliticised issue, States may choose to avoid sensitive issues such as implementing Sustainable Development Goal No 10 on '[reducing] inequality within and among countries' by '[facilitating orderly, safe, regular and responsible migration and mobility of people, including through the implementation of planned and well-managed migration policies' ${ }^{63}$ Further, academic commentators have argued that wealthier and more developed States should be required to make more effort when implementing and prioritising the Sustainable Development Goals, which is not the case for the way the Sustainable Development Goals are currently structured. ${ }^{64}$ While States may prioritise some Sustainable Development Goals over others, some developing States may have fewer resources than other States to implement these goals, thus contributing to a lack of coordination among States for implementing the Sustainable Development Goals. This in turn may increase the chances of the Sustainable Development Goals not being properly implemented, thus widening the protection gap for migrant women and girls.

As aforementioned, therefore, the harmful cycle which increases the vulnerabilities of migrant women and girls may begin with CEDAW provisions that lack punitive measures and 'soft law' guidance instruments that are applied inconsistently or disregarded. This may then lead to the impunity of human rights violators, increasing the likelihood of repeated violations, individual justice for migrant women and girls is thus not achieved, and finally, the potential for exacerbating the vulnerabilities of migrant women and girls. A summary of these key points is represented in the diagram below:

\section{Cycle of Harm often experienced by Migrant Women and Girls in the Migration Process *}

\footnotetext{
62 Bond UK, Implementing the Sustainable Development Goals: Where to Start?, at <bond.org.uk/sites/default/files/bond_sdgs_prioritisation_paper_october_2016.pdf> $>$ (accessed 18 November 2018) (Bond).

63 SDGs, supra nt 37.

64 Bond, supra nt 62, 2.
} 


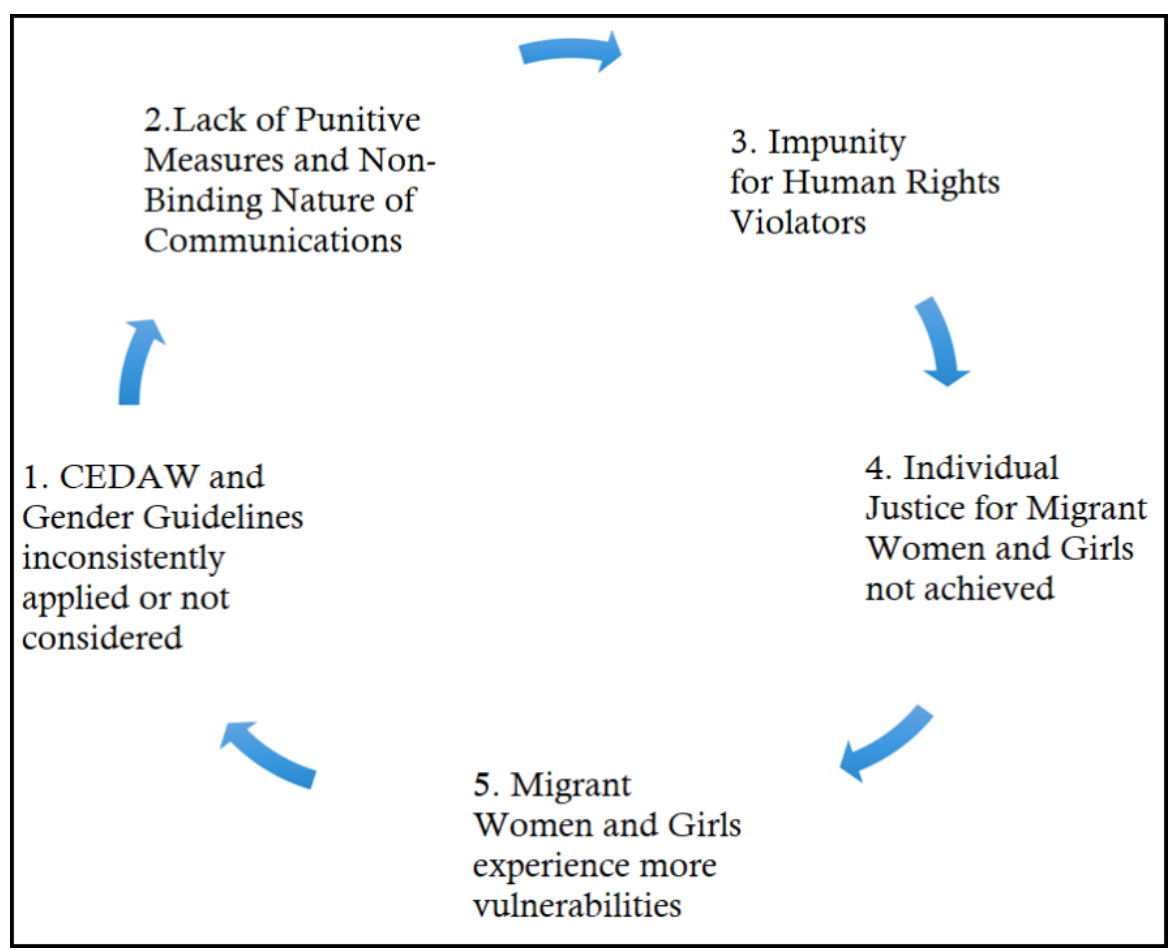

* For illustrative purposes only.

This cycle of harm illustrates that often, inconsistently applying or not considering the Gender Guideline or CEDAW communications may either result in or encourage the lack of punitive measures and reinforces the non-binding nature of the CEDAW Committee's communications. For instance, States parties to CEDAW may have incentives not to follow the CEDAW Committee's communications since they are non-binding. The lack of punitive measures of the international human rights regime for human rights violators, combined with the non-binding nature of CEDAW Committee communications, may result in impunity for violators, thus reducing instances where individual justice may be achieved for migrant women and girls. When individual justice is not achieved for migrant women and girls, their vulnerabilities as both migrants and women and girls may be exacerbated, and they are, in turn, made more vulnerable.

\section{Concluding Remarks}

Migrant women and girls are not passive victims, but with the right tools, they too can be agents of change in spite of their circumstances. The barriers experienced by migrant women and girls are multifaceted, and may include: economic barriers, such as poverty and lack of education; social barriers, such as xenophobia and language difficulties; legal barriers, such as discriminatory laws; and institutional barriers, such as lack of voice in decision-making at all levels in society. Although the Agreed Conclusions of CSW61 stressed the 'positive contribution of migrant women and girls', the 'need to address the special situation and vulnerability of migrant women and girls' and 'the obligation of States to protect the human rights of migrants so as to prevent and address abuse and exploitation', it has been argued that the vulnerabilities of migrant women and girls may be exacerbated by: 
1. The lack of punitive measures for, and the non-binding nature of, CEDAW Committee communications to States parties;

2. The inconsistent application of, and non-consideration of, 'soft law' guidance instruments such as the Gender Guideline; and

3. The lack of coordinated effort among States in the implementation of the Sustainable Development Goals including Target 10.7. ${ }^{65}$

By examining how these three reasons may make migrant women and girls more vulnerable, this article seeks to raise awareness of the situation of these individuals not by highlighting their plight, but by encouraging a more rigorous monitoring of the human rights violations committed towards this group.

The section below will examine the lessons learned from CSW61 and recommendations in light of these areas needing improvement. The best practices relating to enhancing international protection for migrant women and girls will also be discussed.

\section{A. Lessons Learned}

Migrant women and girls are often portrayed as passive victims of their circumstances. Migration itself is highly-gendered, in that the production of migration itself results from the exclusion of women and girls from decision-making at all levels, the prevalence of social barriers, including poverty and limited skills, and the existence of discriminatory laws against women and girls. Furthermore, as reiterated by the UN Assistant Secretary-General, in order for the international law regime to be effective, it must be enabled domestically through national-enabling environments such as through affirmative laws, policies, and measures, the enhancement of financing and investments, gender responsive institutions, as well as data, knowledge, monitoring and accountability ${ }^{66}$ In order to strengthen the international law framework for the protection of migrant women and girls, it is suggested that all stages of migration which concern migrant women and girls should be the target of monitoring and close scrutinising. For example, it has been recommended by the outcome document from the expert meeting in Geneva in November 2016 on the Global Compact for Safe, Orderly and Regular Migration that 'a broad application is adopted so that the rights of women [and girls] at all stages of migration are addressed, promoted and protected in the context of global structural drivers of migration and inequality'. ${ }^{67}$

65 For Agreed Conclusions of CSW61, See, United Nations Economic and Social Council, Women's Economic Empowerment in the Changing World of Work: Agreed Conclusions, E/CN.6/2017/L.5, 27 March 2017, paras 36 and 37, at <undocs.org/en/E/CN.6/2017/L.5> (accessed 18 November 2018) (Agreed Conclusions).

66

UN Women Commission on the Status of Women, Report on CSW61 and Analysis of the Agreed Conclusions: Ms. Lakshmi Puri, UN Assistant Secretary-General and Deputy Executive Director of UN Women, 14-16, at < $<$ lawsdocbox.com/Politics/72122872-Report-on-csw61-and-analysis-of-the-agreed-conclusions-ms-lakshmipuri-un-assistant-secretary-general-and-deputy-executive-director-of-un-women.html> $\quad$ (accessed 18 November 2018).

67 UN Women, Recommendations for Addressing Women's Human Rights in the Global Compact for Safe, Orderly and Regular Migration, November 2016, 4, at <unwomen.org/-/media/headquarters/attachments/ sections/library/publications/2017/addressing-womens-human-rights-migration-en.pdf?la=en\&vs=4301> (accessed 18 November 2018). 


\section{B. Recommendations and Best Practices}

Drawing on the lessons learned at CSW61, some recommendations may be made to improve the situation of migrant women and girls. First, the agency, self-reliance, and resiliency of migrant women and girls should be placed at the forefront and not be undermined in both lawmaking and policy decisions. This allows migrant women and girls to become empowered and not to be portrayed as victims. Secondly, with the right tools, migrant women and girls may be empowered to be agents of change themselves. Thirdly, a comprehensive approach to law and policy-making is required, namely: legal reform to address the harmonisation between international and domestic standards; national economic programs with special focus on migrant women and girls to enable and to empower their resilience; and gender mainstreaming in the business sector and the full participation of women and girls at all levels of decision-making.

Further, migrant women and girls are not a homogenous group. There are migrant women and girls who also experience disabilities, and/or are discriminated based on their sexual orientation (LGBTI) or their ethnic identities as minorities in a community. The response to address the multifaceted vulnerabilities faced by migrant women and girls needs to be tailored to the diversity and economic situation of all migrant women and girls regardless of their race, nationality, religion, gender, sexual orientation or political opinion. In order to enhance the self-reliance of migrant women and girls, there needs to be an implementation of economic interventions to contribute towards the integration and resettlement process of these individuals.

A critique of the lack of enforceability of CEDAW provisions, the inconsistent application or non-consideration of 'soft law' instruments such as the Gender Guideline, and the international human rights regime at large cannot be made without discussing the problems of a State-centric approach to international law. The Westphalian State-centric model encourages top-down implementation of international law obligations. ${ }^{68}$ This model is problematic because it fails to recognise other actors within the international law sphere which includes the rights holders. Arguably, the most neglected and consequently vulnerable group of individuals are the rights holders themselves. It is paradoxical that the international law regime is set up to favour powerful and resourceful States when, at the same time, the primary stakeholders are those with the least bargaining chips at the negotiation table. Often, , the lack of legal status or access to international protection make migrant women and girls vulnerable.

One way this State-centric approach to international law regime may be resisted is by advocating for the bottom-up approach. It is only when the full, equal, and meaningful participation of migrant women and girls at all levels of decision-making, particularly those from developing States, is incorporated that these individuals may achieve self-reliance and resilience. As stated in the Agreed Conclusions of CSW61, addressing the vulnerabilities of migrant women and girls requires a strong alliance among States parties, nongovernmental organisations, and civil society to take part by '[taking] appropriate steps to ensure their full, equal and meaningful participation in the development of local solutions and opportunities' ${ }^{69}$

While there is no overnight solution to the ongoing problems faced by migrant women and girls, the work that needs to be done must start now and must involve incorporating the

\footnotetext{
${ }^{68}$ See generally: Grote, R. "Westphalian System" Max Planck Encyclopedia of Public International Law (2006).

${ }^{69}$ Agreed Conclusions, supra nt 65.
} 
Migrant Rights in International Law: Exploring the Gendered Experiences of Migrant Women and Girls 319

voices of these individuals in decision-making at all levels. This includes cooperation between international organisations such as the United Nations, governments and civil society.

www.grojil.org 